www.jmscr.igmpublication.org

Index Copernicus Value: 79.54

ISSN (e)-2347-176x ISSN (p) 2455-0450

crossrefDOI: https://dx.doi.org/10.18535/jmscr/v7i3.51

\title{
Histopathological Evaluation of Collagen Profiles in Spongiotic Dermatitis
}

\author{
Authors
}

\section{Anjali Patankar, Ramya Gandhi*, Erli Amel Ivan}

Department of Pathology, Sri Manakula Vinayagar Medical College and Hospital, Kalitheerthalkuppam, Puducherry, 605107 India

*Corresponding Author

\section{Dr Ramya Gandhi}

Associate Professor, Department of Pathology, Sri Manakula Vinayagar Medical College and Hospital,

Kalitheerthalkuppam, Puducherry, 605 107, India

Email: ramya2path@yahoo.co.in, Mobile no- 9787740891

\section{Abstract}

Context: Spongiotic Dermatitis is a common clinical condition also known as eczema, characterized by rashes and itching further may progress to scarring. The terms eczema and dermatitis are often used interchangeably to denote a polymorphic inflammatory reaction pattern involving the epidermis and dermis. Spongiosis refers to intraepidermal edema.

Aim: To assess the orientation of collagen in eczematous spongiotic dermatitis.

Material and Methods: The present study was done in the Department of Pathology, Sri Manakula Vinayagar Medical College, Pondicherry. Sixty diagnosed cases of spongiotic dermatitis diagnosed over a period of five years were taken in the study. Orientation of collagen was evaluated using Masson's trichrome stain.

Results: Spongiotic dermatitis occurred in all age groups but commonly seen in middle age to elderly. Male to female ratio was 1:1.2 The most common symptom was itching (85\%) followed by scaling (63.3\%). Most common site was upper extremities (80\%). subacute cases were predominantly seen (38.3\%) followed by chronic cases (33.3\%). The most common orientation of collagen seen was vertical (38.3\%) which was seen in (50\%) of chronic cases.

Conclusion: The study emphasizes the need of using masson trichrome on skin biopsy showing spongiotic dermatitis to assess the collagen orientation and to know its chronicity.

Keywords: Spongiotic dermatitis, collagen, masson's trichrome.

\section{Introduction}

Spongiotic Dermatitis is a common clinical condition also known as Eczema, characterized by rashes and itching, which further may progress to scarring. ${ }^{1}$ Prevalence of Dermatitis in the United States is $10.1 \%{ }^{2}$ The prevalence of atopic eczema in 56 countries had been found to vary between 3 and $20.5 \% .^{3}$
The terms eczema and dermatitis are often used interchangeably to denote a polymorphic inflammatory reaction pattern involving the epidermis and dermis. Spongiosis refers to intraepidermal oedema. ${ }^{1}$ Eczema is caused by a combination of factors that includes genetic factors, environmental factors and abnormal function of immune system. 
Spongiosis describes the appearance of epidermis caused by intercellular edema that results in spaces between keratinocytes, which may progress to intraepidermal vesiculation. The pathophysiologic mechanism of spongiosis remains unknown. It has been proposed that keratinocyte apoptosis induced by T-cells affects transmembrane proteins involved in cell to cell adhesion (cadherins) and that this could be responsible for development of spongiosis. ${ }^{4}$

Spongiotic dermatitis (Eczema) goes through three different stages- acute, subacute, and chronic. It is a dynamic process, and each specific type of dermatitis can progress from acute to chronic phase. ${ }^{5}$ It can progress to scarring hence this present study is undertaken to evaluate the orientation of collagen in eczematous spongiotic dermatitis, because in literature review not much study is available, which have studied the orientation of collagen in skin for eczematous spongiotic dermatitis.

\section{Materials and Method}

The current study was a descriptive and retrospective study conducted in the department of pathology SMVMCH, Pondicherry from may 2013 to may 2017. Sixty histopathologically diagnosed cases of eczematous spongiotic dermatitis were included in study, blocks were retrieved and slides were stained with $H \& E$ and Massons trichrome. H\&E slides were evaluated for categorizing the lesion as acute, subacute or chronic while massons trichrome slides were used to evaluate the orientation of collagen. Data was analyzed using Stata version 14 and results were expressed in percentage while the association of histopathological diagnosis with the orientation of collagen was done using Kruskal Wallis Test

\section{Results}

There were 60 cases of eczematous spongiotic dermatitis included in the study which occurred in all age groups but most commonly seen in middle aged to elderly age group which is shown in Table 1. Female preponderance was seen as shown in
Table 2. Most common clinical presentation was itching (85\%) followed by scaling (63.3\%) Table 3. Most of the lesions were multiple and predominantly distributed on the lower limbs (80\%) followed by chest and abdomen (13.3\%) shown in Table 4. Out of the 60 samples included in the study 17 cases were found to be acute spongiotic dermatitis, 23 were subacute and 20 cases were chronic spongiotic dermatitis Table 5.The most common pattern of orientation seen on masson's trichrome was vertical orientation (38.3\%) shown in Table 7.The pattern seen in chronic phase was vertical $(50 \%)$ In subacute phase equal cases showed vertical to absent collagen (39.1) while in acute phase collagen was predominantly absent(70.6\%) and was found significant shown in Table 7. In acute spongiotic dermatitis the epidermal changes include mild hyperkeratosis, irregular acanthosis, presence of vesiculation, severe spongiosis and exocytosis while the dermal changes include mild vascular proliferation and mild to severe edema. On the other hand the chronic phase shows mild spongiosis, exocytosis and absence of vesiculation while the dermis shows absence of dermal edema with vertical orientation of collagen. Subacute phase shows intermediate features between the acute and chronic phase, summarized in Table 8,9.

Table 1: Distribution of cases according to Age

\begin{tabular}{|c|c|}
\hline Age group (Years) & No of cases \\
\hline $0-20$ & 14 \\
\hline $21-40$ & 15 \\
\hline $41-60$ & 20 \\
\hline$>60$ & 11 \\
\hline
\end{tabular}

Table 2: Distribution of cases as per Gender

\begin{tabular}{|l|c|c|}
\hline Gender & Frequency & Percentage \\
\hline Male & 27 & 45 \\
\hline Female & 33 & 55 \\
\hline Total & 60 & 100 \\
\hline
\end{tabular}

Table 3: Proportion of symptoms

\begin{tabular}{|l|c|c|}
\hline Symptoms & No of cases & Percentage \\
\hline Itching & $\mathbf{5 1}$ & $\mathbf{8 5}$ \\
\hline Scaling & 38 & 63.3 \\
\hline Hyperpigmentation & 29 & 48.3 \\
\hline Erythema & 8 & 13.3 \\
\hline Hypopigmentation & 8 & 13.3 \\
\hline Erosion & 6 & 10 \\
\hline Oozing & 6 & 10 \\
\hline
\end{tabular}


Table 4: Distribution of site in eczematous spongiotic dermatitis

\begin{tabular}{|l|c|c|}
\hline Sites & Frequency & Percentage \\
\hline Face & 2 & 3.3 \\
\hline Chest & 10 & 16.6 \\
\hline Upper limbs & 48 & 80 \\
\hline Abdomen & 10 & 16.6 \\
\hline Lower limbs & 9 & 15 \\
\hline Back & 4 & 6.6 \\
\hline
\end{tabular}

Table 5: Distribution of Histopathological diagnosis in studied samples

\begin{tabular}{|l|c|c|}
\hline Diagnosis & Number of cases & Percentage \\
\hline Acute & 17 & 28.3 \\
\hline Sub-acute & 23 & 38.3 \\
\hline Chronic & 20 & 33.3 \\
\hline Total & 60 & 100 \\
\hline
\end{tabular}

Table 6: Orientation of collagen on masson trichrome stain

\begin{tabular}{|l|c|c|}
\hline Collagen Orientation & Frequency & Percentage \\
\hline Absent & 22 & 36.7 \\
\hline Vertical & 23 & 38.3 \\
\hline Horizontal & 7 & 11.7 \\
\hline Mixed & 8 & 13.3 \\
\hline Total & 60 & 100 \\
\hline
\end{tabular}

Table 7: Association of collagen orientation and histo-pathological diagnosis

\begin{tabular}{|c|c|c|c|c|c|}
\hline & \multicolumn{3}{|c|}{ Histopathological Diagnosis } & \multirow[b]{2}{*}{ p value* } \\
\hline & & $\begin{array}{l}\text { Acute } \\
\text { N (\%) }\end{array}$ & $\begin{array}{c}\text { Sub-acute } \\
\mathbf{N}(\%)\end{array}$ & $\begin{array}{c}\text { Chronic } \\
\text { N }(\%)\end{array}$ & \\
\hline \multirow{5}{*}{ Collagen Orientation } & Absent & $12(70.6)$ & $9(39.1)$ & $1(5)$ & \multirow{5}{*}{$<0.001$} \\
\hline & Vertical & $4(23.5)$ & $9(39.1)$ & $10(\mathbf{5 0})$ & \\
\hline & Horizontal & 0 & $4(17.4)$ & $3(15)$ & \\
\hline & Mixed & $1(5.9)$ & $1(4.3)$ & $6(30)$ & \\
\hline & Total & $17(100)$ & $23(100)$ & $20(100)$ & \\
\hline
\end{tabular}

Table 8: Epidermal Changes

\begin{tabular}{|c|c|c|c|}
\hline $\begin{array}{l}\text { Histopathological } \\
\text { findings }\end{array}$ & $\begin{array}{c}\text { Acute Spongiotic } \\
\text { Dermatitis. } \mathrm{N}=17(\%)\end{array}$ & $\begin{array}{c}\text { Subacute Spongiotic } \\
\text { Dermatitis. } \mathbf{N}=\mathbf{2 3}(\%)\end{array}$ & $\begin{array}{c}\text { Chronic Spongiotic } \\
\text { Dermatitis. } \mathbf{N}=\mathbf{2 0}(\%)\end{array}$ \\
\hline $\begin{array}{l}\text { Hyperkeratosis } \\
\text { Mild } \\
\text { Moderate } \\
\text { Severe } \\
\text { Absent }\end{array}$ & $\begin{array}{c}70.6 \% \\
11.8 \% \\
0 \% \\
17.6 \% \\
\end{array}$ & $\begin{array}{l}78.3 \% \\
8.7 \% \\
4.3 \% \\
8.7 \% \\
\end{array}$ & $\begin{array}{c}35 \% \\
30 \% \\
30 \% \\
5 \% \\
\end{array}$ \\
\hline $\begin{array}{l}\text { Parakeratosis } \\
\text { Mild } \\
\text { Moderate } \\
\text { Severe } \\
\text { Absent }\end{array}$ & $\begin{array}{c}41.2 \% \\
11.8 \% \\
5.9 \% \\
41.2 \%\end{array}$ & $\begin{array}{c}30.4 \% \\
13 \% \\
4.3 \% \\
52.2 \% \\
\end{array}$ & $\begin{array}{c}50 \% \\
25 \% \\
0 \% \\
25 \%\end{array}$ \\
\hline $\begin{array}{l}\text { Acanthosis } \\
\text { Regular } \\
\text { Irregular } \\
\text { Absent } \\
\end{array}$ & $\begin{array}{l}23.5 \% \\
52.9 \% \\
23.5 \% \\
\end{array}$ & $\begin{array}{c}30.4 \% \\
56.5 \% \\
13 \% \\
\end{array}$ & $\begin{array}{l}45 \% \\
30 \% \\
25 \% \\
\end{array}$ \\
\hline $\begin{array}{l}\text { Vesiculation } \\
\text { Absent } \\
\text { Present }\end{array}$ & $\begin{array}{l}35.3 \% \\
64.7 \%\end{array}$ & $\begin{array}{l}56.5 \% \\
43.5 \% \\
\end{array}$ & $\begin{array}{c}95 \% \\
5 \%\end{array}$ \\
\hline $\begin{array}{l}\text { Spongiosis } \\
\text { Mild } \\
\text { Moderate } \\
\text { Severe } \\
\text { Absent } \\
\end{array}$ & $\begin{array}{c}23.5 \% \\
29.4 \% \\
41.2 \% \\
5.9 \% \\
\end{array}$ & $\begin{array}{c}17.4 \% \\
60.9 \% \\
21.5 \% \\
0 \% \\
\end{array}$ & $\begin{array}{c}90 \% \\
5 \% \\
0 \% \\
5 \% \\
\end{array}$ \\
\hline $\begin{array}{c}\text { Exocytosis } \\
\text { Absent } \\
\text { Present } \\
\end{array}$ & $\begin{array}{l}41.2 \% \\
58.8 \%\end{array}$ & $\begin{array}{l}43.5 \% \\
56.5 \% \\
\end{array}$ & $\begin{array}{l}30 \% \\
70 \%\end{array}$ \\
\hline $\begin{array}{l}\text { Papillomatosis } \\
\text { Absent } \\
\text { Present }\end{array}$ & $\begin{array}{l}88.2 \% \\
11.8 \% \\
\end{array}$ & $\begin{array}{l}82.6 \% \\
17.4 \% \\
\end{array}$ & $\begin{array}{l}75 \% \\
25 \% \\
\end{array}$ \\
\hline $\begin{array}{l}\text { Granular layer } \\
\text { Normal } \\
\text { Hypogranular } \\
\text { Hypergranular }\end{array}$ & $\begin{array}{l}58.8 \% \\
23.5 \% \\
17.6 \%\end{array}$ & $\begin{array}{l}52.2 \% \\
26.1 \% \\
21.7 \%\end{array}$ & $\begin{array}{c}40 \% \\
0 \% \\
60 \%\end{array}$ \\
\hline
\end{tabular}




\section{JMSCR Vol||07||Issue||03||Page 281-286||March}

Table 9: Dermal Changes

\begin{tabular}{|l|c|c|c|}
\hline Histopathological findings & $\begin{array}{c}\text { Acute spongiotic } \\
\text { dermatitis. N=17(\%) }\end{array}$ & $\begin{array}{c}\text { Subacute spongiotic } \\
\text { dermatitis. N=23(\%) }\end{array}$ & $\begin{array}{c}\text { Chronic spongiotic } \\
\text { dermatitis. N=20(\%) }\end{array}$ \\
\hline Dermal edema & & & \\
Mild & $11.8 \%$ & $34.8 \%$ & $20 \%$ \\
Moderate & $58.8 \%$ & $47.8 \%$ & $5 \%$ \\
Severe & $23.5 \%$ & $4.3 \%$ & $0 \%$ \\
Absent & $13 \%$ & $13 \%$ & $75 \%$ \\
\hline Vascular proliferation & & & \\
Absent & $11.8 \%$ & $17.4 \%$ & $15 \%$ \\
Mild & $52.9 \%$ & $47.8 \%$ & $70 \%$ \\
Moderate & $29.4 \%$ & $30.4 \%$ & $15 \%$ \\
Severe & $5.9 \%$ & $4.3 \%$ & $0 \%$ \\
\hline Inflammatory cells & & & $40 \%$ \\
Chronic & $23.5 \%$ & $13.04 \%$ & $0 \%$ \\
Chronic+Neutrophils & $23.5 \%$ & $26.08 \%$ & $45 \%$ \\
Chronic+Eosinophils & $23.5 \%$ & $39.1 \%$ & $15 \%$ \\
Chronic+N+E & $29.4 \%$ & $21.7 \%$ & \\
\hline Collagen orientation on & & & $50 \%$ \\
MT & & $39.1 \%$ & $15 \%$ \\
Vertical & $23.5 \%$ & $17.4 \%$ & $30 \%$ \\
Horizontal & $0 \%$ & $4.3 \%$ & $5 \%$ \\
Mixed & $5.9 \%$ & $39.1 \%$ & \\
Absent & $70.6 \%$ & & \\
\hline
\end{tabular}

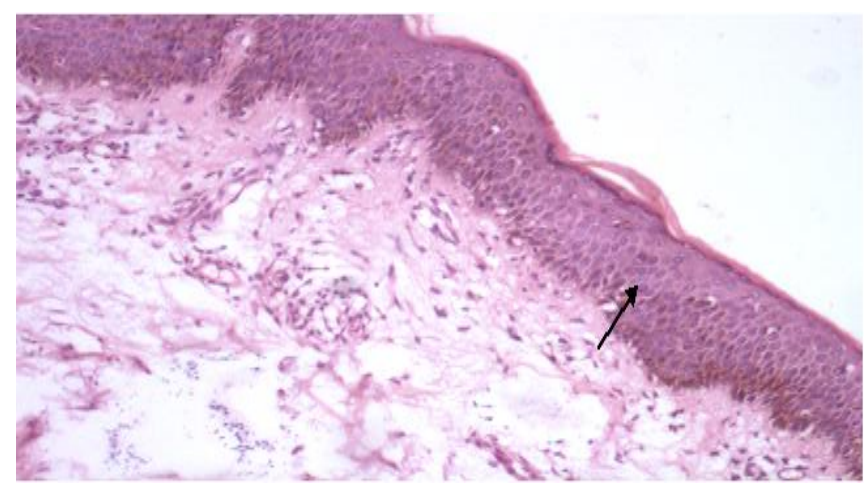

Image 1: Acute spongiotic dermatitis with severe spongiosis(arrow), severe dermal edema (H\&E, 100X)

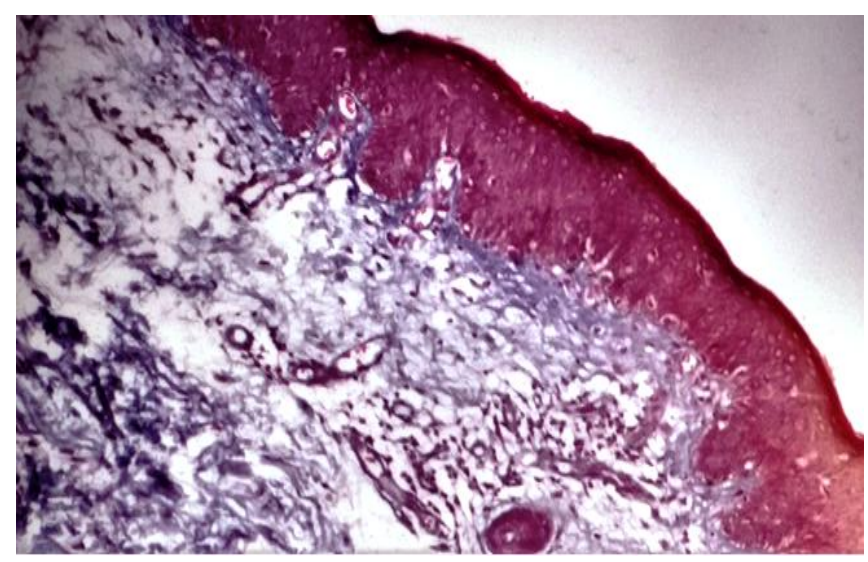

Image 2: Vertical orientation of collagen fibers. (100X, Masson trichrome)

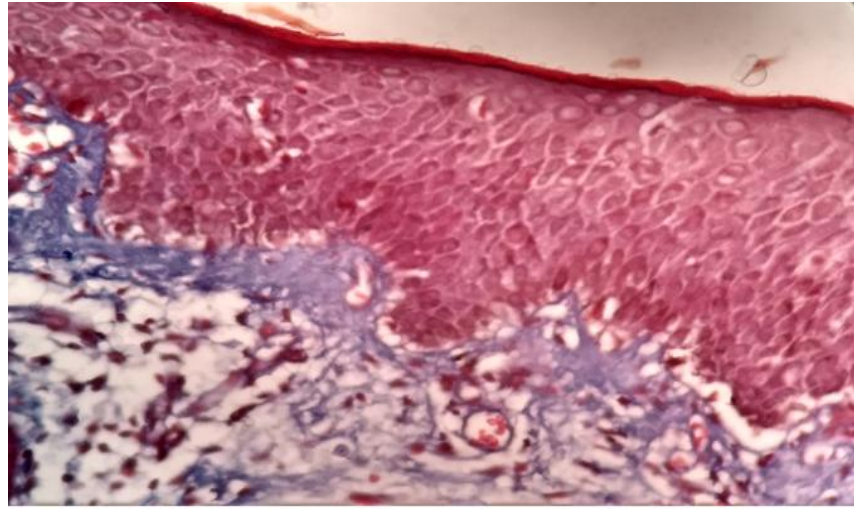

Image 3: Horizontal orientation of collagen (100X, Masson trichrome)

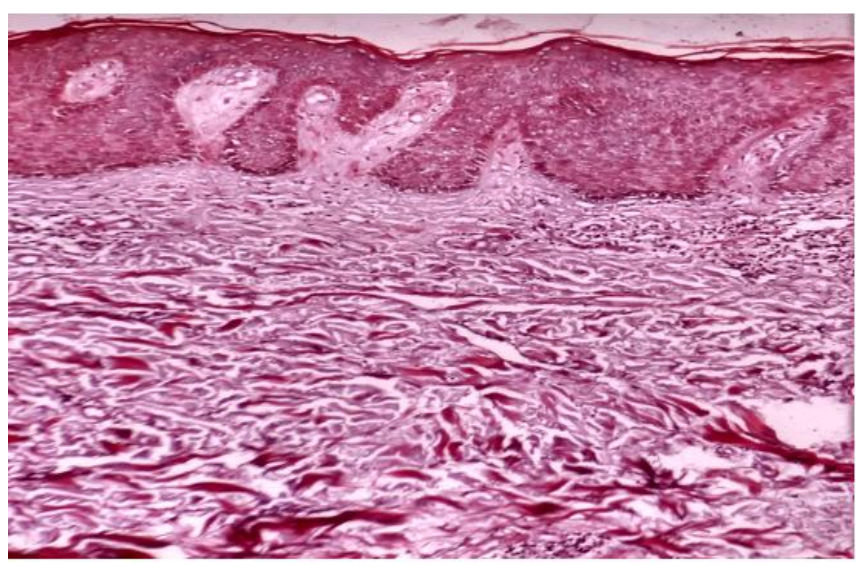

Image 4: Mixed pattern of collagen orientation. (H\&E,100X) 


\section{Discussion}

Eczematous spongiotic dermatitis is defined by the presence of intraepidermal edema. ${ }^{5}$ It is caused by different types of eczema. Spongiotic dermatitis can further be classified as acute, subacute and chronic based on the time the biopsy is performed. The present study categorized the biopsies into acute, subacute and chronic based on different histopathological parameters.

Hesari et $\mathrm{al}^{6}$ got similar results like the present study which showed female preponderance. The most common clinical presentation in a study by Raghu et $\mathrm{al}^{7}$ was pruritus followed by scaling which was consistent with the findings in the present study.

Out of the total 60 cases diagnosed as spongiotic dermatitis analysis showed $38.3 \%$ of subacute, $33.3 \%$ of chronic and $28 \%$ of acute spongiotic dermatitis. This finding correlates with similar study done by Gupta K where subacute cases were most common. ${ }^{8}$

Least cases were of acute spongiotic dermatitis $(28 \%)$ in the present study as it is the earliest phase and least biopsied stated by S.D. Billing and J. Cotton. ${ }^{9}$

In Lever's histopathology of skin it is stated that in chronic spongiotic dermatitis, papillary dermal fibrosis is a predominant feature due to increased number of fibroblasts and vertical oriented collagen bundles reflects lichen simplex chronicus (a prototype of chronic dermatitis). As rubbing increases in intensity and chronicity, the fibrosis becomes more marked. ${ }^{10}$ this finding is in consistence with the present study which showed maximum cases with vertical orientation of collagen that too predominantly in chronic phase.

With chronicity of lesions in eczematous spongiotic dermatitis the content of collagen increases in the dermis so only topical treatment alone would not be of much help therefore this finding should warrant the clinicians to use an aggressive treatment like intralesional injections of steroid as this would benefit the patient by minimizing the scar.

\section{Conclusion}

With the progression of lesion from acute, subacute to chronic there is increased acanthosis, hyperkeratosis and papillomatosis which correlates with the increased vertical orientation of collagen in dermis, therefore orientation of collagen is an important parameter in assessing the chronicity of lesions hence masson's trichrome stain along with $\mathrm{H} \& \mathrm{E}$ can be used routinely. For further assessment other special stains are required like picrosirious red, which needs further studies.

\section{Acknowledgment}

We are thankful to the Department of Dermatology for sending the skin biopsies.

\section{Conflict of Interest}

No conflict of interest.

\section{References}

1. Phelps RG, Miller MK, Singh F. The varieties of eczema; clinico pathologic correlation. Clin Dermatol 2003 MarApr;21(2):95-100.

2. Hanifin J, Reed M. A population-based survey of eczema prevalence in the United States. Dermatitis 2007;18(2):82-91.

3. Beasley R. Worldwide variation in prevalence of symptoms of asthma, allergic rhinoconjunctivitis, and atopic eczema: ISAAC. The Lancet 1998;351(9111):1225-1232.

4. Trautmann A, Altznauer F, Akdis M, Simon HU, Disch R, Brpcker EB et al. The differential fate of cadherins during $\mathrm{T}$ cell-induced keratinocyte apoptosis leads to spongiosis in eczematous dermatitis. $\mathbf{J}$ Invest Dermatol 2001 Oct;117(4):927-934.

5. Houck G, Saeed S, Stevens GL, Morgan MB. Eczema and the spongiotic dermatoses: A histologic and pathogenic update. Semin Cutan Med Surgery 2004;23(1):39-45.

6. Hesari KK, Naraghi SZ, Ghanadan A, Nikoo A, Sabaghi M. Palmoplantar 
Psoriasis versus Eczema: Major

Histopathologic Clues for Diagnosis. Iran J Pathol 2014;9(4):251-256.

7. Raghu MT, Aravind K, Parvathi CN. A study of clinical types of contact allergic dermatitis of hands and its association with allergens. International Journal of Applied Research 2015;1(9):643-650.

8. Gupta K. Deciphering spongiotic dermatitides. Indian J Dermatol Venereol Leprol 2008;74(5):523-526.

9. Billings $\mathrm{SD}$, Cotton J. Inflammatory dermatopathology. A pathologist's survival guide. New York: Springer; 2011. p.5-16.

10. Elder ED. Lever's histopathology of the skin. In: Velazquez EF, Murphy GF, editors. Histology of skin. 10th ed. Philadelphia: Wolters Kluwer/Lippincott Williams \& Williams; 2009. p. 29-66. 